\title{
Growth and Yield of Boro Rice (BRRI Dhan 50) as Affected by Planting Geometry under System of Rice Intensification
}

\author{
Sudip Chakrabortty ${ }^{1}$, P. K. Biswas ${ }^{1}$, T. S. Roy ${ }^{1}$, M.A.A. Mahmud ${ }^{2}$, H. Mehraj ${ }^{3}$ and A. \\ F. M. Jamal Uddin ${ }^{3 *}$ \\ Dept. of Agronomy, Sher-e-Bangla Agricultural University, Dhaka ${ }^{1}$ \\ Dept. of Animal Nutrition, Sylhet Agricultural University, Sylhet ${ }^{2}$ \\ Dept. of Horticulture, Sher-e-Bangla Agricultural University, Dhaka, Bangladesh ${ }^{3}$ \\ Corresponding author*: jamal4@yahoo.com
}

\begin{abstract}
Rice (Oryza sativa L.) is the staple crop in Bangladesh and different factors influence its productivity. Among these factors, desired number of plant spacing per unit area is important for higher yield attainment.Therefore, this study were undertaken to define the optimum plant geometry for getting the maximum yield. The experiment was conducted at Agronomy field, Sher-e-Bangla Agricultural University during December, 2011 to May, 2012 to study the growth and yield of Boro rice (BRRI dhan 50) as affected by planting geometry under System of Rice Intensification (SRI). Experiment comprised 5 level of plant spacing, viz. $S_{1}: 25 \mathrm{~cm} \times 25$ $\mathrm{cm}, S_{2}: 30 \mathrm{~cm} \times 30 \mathrm{~cm}, S_{3}: 35 \mathrm{~cm} \times 35 \mathrm{~cm}, S_{4}: 40 \mathrm{~cm} \times 40 \mathrm{~cm}$ and $S_{5}: 25 \mathrm{~cm} \times 15 \mathrm{~cm}$ following Completely Randomized Block Design with three replication. Maximum dry matter (156.2 g/hill), number of tiller (44.0/hill), number of effective tiller (36.3/hill), number of filled grains (101.5/panicle), grain yield (6.9 t/ha), straw yield (5.9 t/ha), biological yield (12.7 t/ha) and harvest index (54.5\%) was found from $40 \times 40 \mathrm{~cm}$ plant spacing while minimum was observed from $25 \times 25 \mathrm{~cm}$ of plant spacing in this study.
\end{abstract}

Key words: Oryza sativa, planting geometry, growth and yield

\section{Introduction}

Rice (Oryza sativa L.) is the staple crop in Bangladesh and its production cannot fulfill the requirements due to the shortage of cultivable land. So, special attention should be given for increasing the yield per unit area. The crop depends largely on temperature, solar radiation, moisture and soil fertility for their growth and nutritional requirements. A thick population crop may have limitations in the maximum availability of these factors. Optimum plant spacing influences the availability of sunlight and nutrients for growth and development. Among the different factors of rice productivity, desired number of plant spacing per unit area is an important one for getting higher yield (Soratto, 2004). Improper spacing reduced yield up to 20-30\% (IRRI, 1997) while optimum spacing ensures better plant growth through efficient utilization of solar radiation and nutrients (Khan et al., 2005; Mohaddesi et al., 2011). Plant spacing directly affects the normal physiological activities through intra-specific competition (Oad et al., 2001). Wider space allows the individual plants to produce more tillers but it provides the smaller number of hills per unit area which results in low grain yield (Baloch et al., 2002; Vijayakumar et al., 2004; Gozubenli, 2010; Kandil et al., 2010). Maintenance of a critical level of rice plant population in field is necessary to maximize grain yields. The effect of plant density on kernel dimension was also identified during different panicle development stages 
(Senanayake et al., 1991; Banik et al., 1997; Wang and Luo, 1998). Current study were undertaken to determine the optimum plant geometry for getting the maximum yield in BRRI Dhan 50.

\section{Materials and Method}

Experimental site and duration: This experiment was conducted in Agronomy farm, Sher-e-Bangla Agricultural University, Dhaka, Bangladesh from December, 2011 to May, 2012.

Treatments and experimental design: Experiment consisted five different plant spacing viz. $\mathrm{S}_{1}: 25$ $\mathrm{cm} \times 25 \mathrm{~cm}, \mathrm{~S}_{2}: 30 \mathrm{~cm} \times 30 \mathrm{~cm}, \mathrm{~S}_{3}: 35 \mathrm{~cm} \times 35 \mathrm{~cm}, \mathrm{~S}_{4}: 40 \mathrm{~cm} \times 40 \mathrm{~cm}$ and $\mathrm{S}_{5}: 25 \mathrm{~cm} \times 15 \mathrm{~cm}$ following Completely Randomized Block Design with three replications.

Planting material: The seeds of BRRI Dhan 50 were collected from Bangladesh Rice Research Institute (BRRI), Joydebpur, Gazipur.

Fertilization: The fertilizers N, P, K, S, Zn and B in the form of urea $\left(150 \mathrm{~kg} \mathrm{ha}^{-1}\right)$, TSP $\left(100 \mathrm{~kg} \mathrm{ha}^{-1}\right)$, MP $\left(\mathrm{kgha}^{-1}\right)$, gypsum $\left(60 \mathrm{~kg} \mathrm{ha}^{-1}\right)$, zinc sulphate $\left(10 \mathrm{~kg} \mathrm{ha}^{-1}\right)$ and borax $\left(10 \mathrm{~kg} \mathrm{ha}^{-1}\right)$ respectively were applied. Entire amount of TSP, MP, gypsum, zinc sulphate and borax were applied during final preparation of plot land. Mixture of cowdung and compost $\left(10\right.$ tha $\left.^{-1}\right)$ was applied during 15 days before transplantation. Urea was applied in three equal installments at after recovery, tillering and before panicle initiation (BRRI, 2012).

Data collection: Data were collected on plant height, number of tillers/hill, leaf area index, dry matter/hill, effective tillers/hill, ineffective tillers/hill, panicle length, filled grains/panicle, unfilled grains/panicle, weight of 1000-grains, grain yield, straw yield, biological yield, harvest index, weed population $/ \mathrm{m}^{2}$ and weed dry matter $/ \mathrm{m}^{2}$. Leaf area index measured manually and final data calculated multiplying by a correction factor 0.75 as per Yoshida (1981). Collected plants including roots (after uprooting), leaves, grain and straw were oven dried at $70^{\circ} \mathrm{C}$ for 72 hours then transferred into desiccator and allowed to cool down at room temperature, final weight was taken and converted into dry matter content/hill.

The biological yield was calculated using the following formula:

Biological yield $=$ Grain yield + Straw yield

Harvest Index (HI) was calculated by following formula:

$$
\mathrm{HI}(\%)=\{\text { Economic yield }(\text { grain weight }) \div \text { Biological yield }(\text { Total dry weight })\} \times 100
$$

Statistical analysis: Collected data were statistically analyzed using IRRISTAT software to observe the significant difference among the treatments. The mean values of all the characters were calculated and analysis of variance was performed. The significance of the difference among the treatment means was estimated by the Least Significant Difference (LSD) test at 5\% level of probability (Gomez and Gomez, 1984).

\section{Results and Discussion}

\section{Plant height and Leaf Area Index (LAI)}

Plant height was not varied significantly among different plant spacing at different DAT (days after transplanting). However, tallest plant was found from $S_{3}(76.9 \mathrm{~cm})$ while shortest from $S_{1}(75.2 \mathrm{~cm})$ at 120 DAT (Figure 1a). Wider spacing of $40 \times 40 \mathrm{~cm}$ found to have significant influence on growth 
parameters (Krishna et al.,2008). Plant height was found significant difference among sixteen varieties in SRI system (Tohiduzzaman, 2011).The closest spacing produced the shortest plant; it might be due to more competition for nutrient, moisture, space and light among the plants in closest spacing.

LAI of rice varied significantly among the different plant spacing as different DAT. Maximum LAI was found from $\mathrm{S}_{5}$ (4.5) while minimum from $\mathrm{S}_{4}(2.5)$ at 120 DAT (Fig. 1b). Significant difference among sixteen varieties in leaf area index was found in SRI system (Tohiduzzaman, 2011). The seedling density affects the plant growth due to its direct relation with plant population. The higher plant population increases competition among plants for nutrients, light and space, while lower population density causes inefficient use of natural resources and inputs (Lone et al., 2010). The total dry weight of leaves, leaf area index (LAI) was decreased with increasing plant densities (Rad et al., 1999).

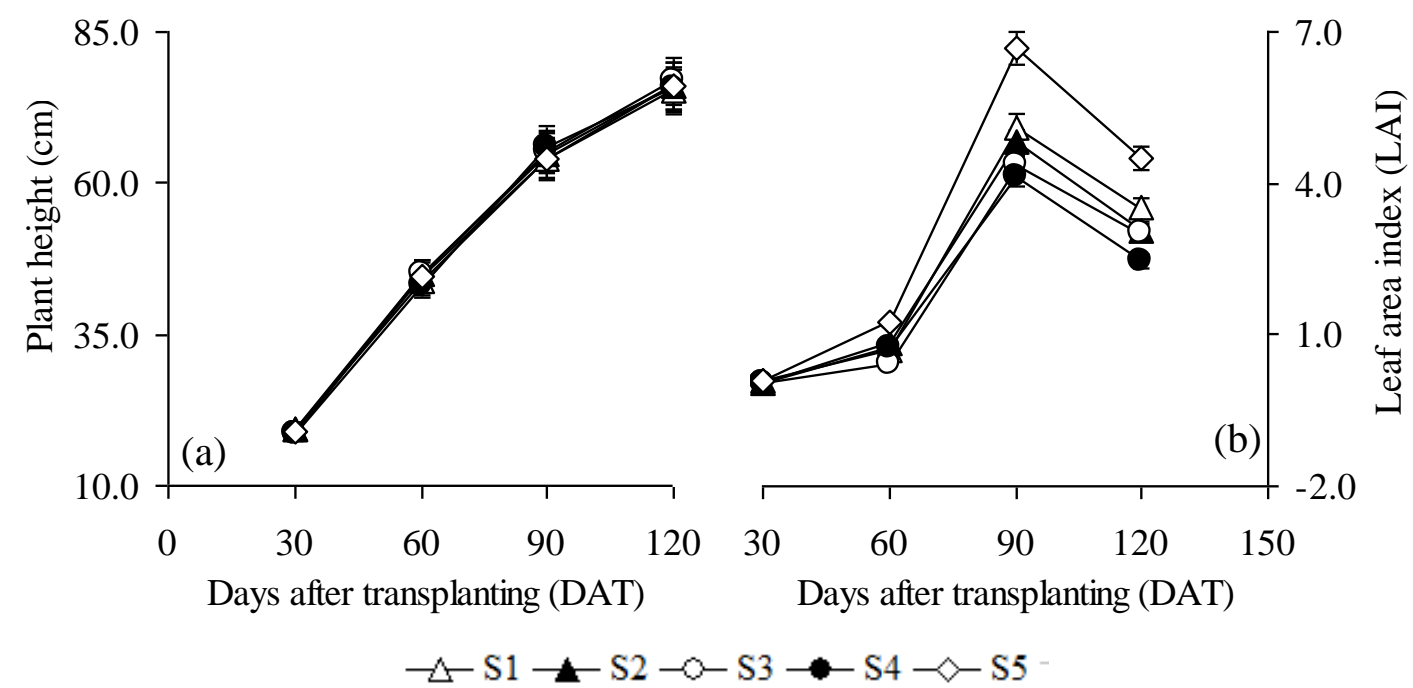

Figure 1. (a) Plant height and (b) Leaf Area Index of BRRI Dhan 50

\section{Dry matter/hill and number of tillers/hill}

Plant spacing showed a significant variation for dry matter/hill in rice. Maximum dry matter was found from $\mathrm{S}_{4}(156.2 \mathrm{~g} / \mathrm{hill})$ while minimum from $\mathrm{S}_{5}(44.6 \mathrm{~g} / \mathrm{hill})$ which was statistically identical with $\mathrm{S}_{1}$ (50.8 g/hill) (Figure 2a). Significant difference among sixteen varieties was found for dry matter/hill in SRI system (Tohiduzzaman, 2011). Significantly higher dry matter accumulation was recorded in BI43 with $30 \mathrm{~cm} \times 30 \mathrm{~cm}$ spacing under direct seeding (Sridhara et al., 2011). Process of dry matter accumulation in all planting densities has been presented in figure 4 . With density increasing, plant number per area, leaf area and photosynthetic organs would be increased that causes improve in dry matter material. These findings are similar to Shekari (2001) results on millet.

Number of tiller/hill was varied significantly among the different plant spacing of rice. However, maximum number of tillers was found from $S_{4}\left(44.0 /\right.$ hill) followed by $S_{3}(40.7 /$ hill) while minimum from $S_{5}(19.5 /$ hill) (Figure 2b). Number of tillers and panicles per unit area were higher in closer spacing (Karmakar et al., 2004). Significant difference was found for number of tillers among sixteen varieties due to the variation of plant height in SRI system (Tohiduzzaman, 2011). Higher tiller numbers/plant was found to greater space (Balasubramaniyan and Palaniappan, 1991) due to increased levels of soil fertility, less competition among the plants also larger row spacing will promote production of healthier and more panicle bearing tillers. In contrast, with limited soil fertility, crowded plant population will produce lest panicle fertile tillers. 


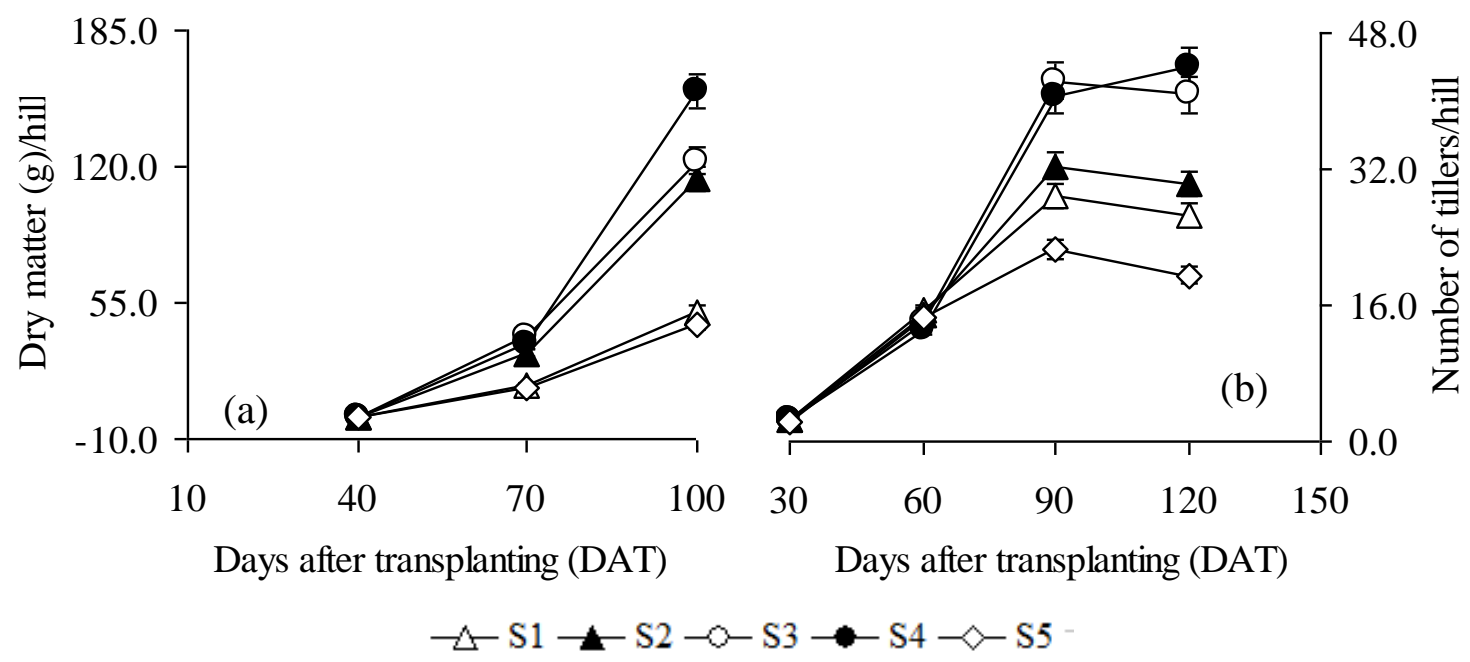

Figure 2. (a) Dry matter/hill and (b) Number of tiller/hill of BRRI Dhan 50

\section{Number of effective tillers}

Maximum number of effective tillers was found from $S_{4}$ (36.3/hill) while minimum from $S_{5}(18.3 /$ hill $)$ (Table 1). Significant difference was found for number of effective tillers among sixteen varieties due to the variation of plant height in SRI system (Tohiduzzaman, 2011). In wider spacing plants absorbed more nutrient, moisture and light which resulted on more number of effective tillers hill-1. This result was agreement with that view of Miah et al. (1990).

\section{Number of ineffective tillers}

Minimum number of ineffective tillers was found from $S_{5}$ (1.7/hill) while maximum from $S_{4}$ (3.3/hill) (Table 1). Significant difference was found for number of ineffective tillers among sixteen varieties due to the variation of plant height in SRI system (Tohiduzzaman, 2011).

\section{Panicle length}

Longest panicle was found from $\mathrm{S}_{2}(23.4 \mathrm{~cm})$ which was statistically identical with $\mathrm{S}_{3}(23.1 \mathrm{~cm})$ while minimum from $S_{5}(22.1 \mathrm{~cm})$ (Table 1). Significant difference was found for panicle length among sixteen varieties due to the variation of plant height in SRI system (Tohiduzzaman, 2011).

\section{Number of filled grains}

Maximum number of filled grain was found from $S_{4}$ (101.5/panicle) while minimum from $S_{1}$ (94.0/panicle) which was statistically identical with $S_{2}$ (94.7/panicle) (Table 1). Significant difference was found for filled grains numbers among sixteen varieties due to the variation of plant height in SRI system (Tohiduzzaman, 2011). Veeramani (2011) reported significant higher number of filled grains/panicle at wider row spacing of $30 \mathrm{~cm} \times 25 \mathrm{~cm}$ compared with closer pacing of $25 \mathrm{~cm} \times 25 \mathrm{~cm}$. Number of grains/panicle of rice varied significantly among different plant spacing (Awan et al., 2006 and 2007)

\section{Number of unfilled grains}

Maximum number of unfilled grains was found from $\mathrm{S}_{4}$ (26.5/panicle) which was statistically identical with $S_{3}\left(26.3 /\right.$ panicle) and $S_{1}$ (26.1/panicle) while minimum from $S_{2}$ and $S_{5}$ (24.8/panicle) (Table 1). 
Significant difference was found for number of unfilled grains among sixteen varieties due to the variation of plant height in SRI system (Tohiduzzaman, 2011).

\section{0-grain weight}

Maximum 1000-grain weight was found from $\mathrm{S}_{2}(19.0 \mathrm{~g})$ which was statistically identical with $\mathrm{S}_{4}$ $(18.9 \mathrm{~g})$ while minimum from $\mathrm{S}_{1}(17.9 \mathrm{~g})$ (Table 1). Significant difference was found for 1000-grain weight due to the variation of plant spacing (Tohiduzzaman, 2011; Awanet al., 2011). When there are more spacing there will be more air, light and inputs availability and that may responsible for maximum 1000 grain weight. Increase in grain weight at higher nitrogen rates might be primarily due to increase in chlorophyll content of leaves which led to higher photosynthetic rate and ultimately plenty of photosynthates available during grain.

Table 1. Responses of different plant spacing on yield related attributes of BRRI Dhan $50^{\mathrm{X}}$

\begin{tabular}{|c|c|c|c|c|c|c|c|c|}
\hline $\begin{array}{l}\text { Plant } \\
\text { spacing }\end{array}$ & $\begin{array}{l}\text { Number of } \\
\text { effective } \\
\text { tillers/hill }\end{array}$ & $\begin{array}{l}\text { Number of } \\
\text { ineffective } \\
\text { tillers/hill }\end{array}$ & $\begin{array}{l}\text { Panicle } \\
\text { length } \\
\text { (cm) }\end{array}$ & $\begin{array}{c}\text { Number of } \\
\text { filled } \\
\text { grains/panicle }\end{array}$ & $\begin{array}{c}\text { Number of } \\
\text { unfilled } \\
\text { grains/panicle }\end{array}$ & $\begin{array}{r}10 \\
\text { gr } \\
\text { weig }\end{array}$ & $\begin{array}{l}0- \\
\text { in } \\
\text { at }(\mathrm{g})\end{array}$ & $\begin{array}{l}\text { Grain } \\
\text { yield } \\
\text { (t/ha) }\end{array}$ \\
\hline $\mathrm{S}_{1}$ & $21.1 \mathrm{~cd}$ & $2.3 \mathrm{bc}$ & $22.7 \quad b$ & $94.0 \mathrm{~d}$ & $26.1 \quad \mathrm{a}$ & 17.9 & $\mathrm{c}$ & $4.8 \mathrm{~b}$ \\
\hline $\mathrm{S}_{2}$ & $24.8 \quad \mathrm{c}$ & $2.7 \quad a b$ & $23.4 \quad \mathrm{a}$ & $94.7 \quad d$ & $24.8 \quad \mathrm{~b}$ & 19.0 & $\mathrm{a}$ & 3.4 \\
\hline $\mathrm{S}_{3}$ & $31.9 \quad \mathrm{~b}$ & $3.0 \quad a b$ & $23.1 \quad \mathrm{a}$ & $96.1 \quad \mathrm{c}$ & $26.3 \quad \mathrm{a}$ & 18.3 & $\mathrm{~b}$ & 4.1 \\
\hline $\mathrm{S}_{4}$ & $36.3 \quad \mathrm{a}$ & $3.3 \quad \mathrm{a}$ & $22.9 \quad b$ & $101.5 \mathrm{a}$ & $26.5 \mathrm{a}$ & 18.9 & $\mathrm{a}$ & 6.9 \\
\hline $\mathrm{S}_{5}$ & $18.3 \mathrm{~d}$ & $1.7 \mathrm{c}$ & $22.1 \quad \mathrm{c}$ & $98.9 \quad b$ & $24.8 \quad \mathrm{~b}$ & 18.1 & $\mathrm{c}$ & 5.2 \\
\hline & 4.1 & 0.7 & 0.4 & 0.8 & 1.7 & 0.5 & & 0.6 \\
\hline $\mathrm{CV}(\%)$ & 4.1 & 5.8 & 6.6 & 1.6 & 5.3 & 2.4 & & 8.9 \\
\hline
\end{tabular}

${ }^{\mathrm{X}}$ In a column, means having similar letter(s) are statistically similar and those having dissimilar letter(s) differ significantly at 0.05 level of probability

\section{Grain yield}

Maximum grain yield was from $S_{4}\left(6.9\right.$ t/ha) while minimum from $S_{3}(4.1 \mathrm{t} / \mathrm{ha})$ (Table 1). Significant difference was found for grain yield among sixteen varieties due to the variation of plant height in SRI system (Tohiduzzaman, 2011). SRI recommended wider spacing $(25 \mathrm{~cm} \times 25 \mathrm{~cm}$ to $30 \mathrm{~cm} \times 30 \mathrm{~cm})$ for higher yields (Batuwitage, 2000). Singh et al. (1983) studied the effect of row spacing in combination with nutrient supply on grain yield of semi-dwarf upland rice variety Narendra 1 (IET 2232) and found more grain yield with $20 \mathrm{~cm}$ spacing as compared to the others. The plant density at spacing of $20 \times 20 \mathrm{~cm}^{2}$ was more effective and gave significantly higher grain yield than $25 \times 25 \mathrm{~cm}^{2}$ and $15 \times 15 \mathrm{~cm}^{2}$ (Bari et al., 1984).

\section{Straw yield}

Maximum straw yield was found from $\mathrm{S}_{4}(5.9 \mathrm{t} / \mathrm{ha})$ which was statistically identical with $\mathrm{S}_{5}(5.5 \mathrm{t} / \mathrm{ha})$ while minimum from $S_{2}(3.2 \mathrm{t} / \mathrm{ha}$ ) (Table 2). Significant difference was found for straw yield among sixteen varieties due to the variation of plant height in SRI system (Tohiduzzaman, 2011). Bozorgiet al. (2011) also found significant variation in straw yield of rice on different plant spacing of rice.

\section{Biological yield}

Maximum biological yield was found from $\mathrm{S}_{4}(12.7 \mathrm{t} / \mathrm{ha})$ followed by S5 $(10.7 \mathrm{t} / \mathrm{ha})$ while minimum from $S_{3}\left(8.3 \mathrm{t} / \mathrm{ha}\right.$ ) and $S_{1}(9.2 \mathrm{t} / \mathrm{ha}$ ) (Table 2). Significant difference was found for biological yield among sixteen varieties due to the variation of plant height in SRI system (Tohiduzzaman, 2011). Biological yield varied due to the variation of planting density (Bozorgi et al., 2011). 


\section{Harvest index (HI)}

Harvest index showed a non-significant variation among the different plant spacing. However, maximum HI was found from $S_{4}(54.5 \%)$ while minimum from $S_{5}(50.3 \%)$ (Table 2). Significant difference was found for harvest index among sixteen varieties due to the variation of plant height in SRI system (Tohiduzzaman, 2011). Bozorgi et al. (2011) also found significant variation in harvest index of rice on different plant spacing of rice.

\section{Number of weed population}

Maximum number of weed population was found from $S_{2}\left(61.3 / \mathrm{m}^{2}\right)$ which was statistically identical with $\mathrm{S}_{5}\left(55.9 / \mathrm{m}^{2}\right)$ while minimum from $\mathrm{S}_{4}\left(38.0 / \mathrm{m}^{2}\right)$ at 30 DAT (Table 2). On the other hand, maximum number of weed population was found from $S_{3}\left(84.3 / \mathrm{m}^{2}\right)$ while minimum from $S_{1}\left(65.8 / \mathrm{m}^{2}\right)$ (Table 2).

\section{Weed dry matter}

Weed dry matter showed a non-significant variation among the different plant spacing at 30 DAT and 60 DAT. Maximum weed dry matter was found from $\mathrm{S}_{2}\left(2.8 \mathrm{~g} / \mathrm{m}^{2}\right)$ while minimum from $\mathrm{S}_{3}$ and $\mathrm{S}_{4}(2.2$ $\left.\mathrm{g} / \mathrm{m}^{2}\right)$ at 30 DAT. On the other hand, maximum weed dry matter was found from $\mathrm{S}_{3}\left(3.6 \mathrm{~g} / \mathrm{m}^{2}\right)$ while minimum from $\mathrm{S}_{1}\left(3.0 \mathrm{~g} / \mathrm{m}^{2}\right)$ (Table 2$)$.

Table 2. Effect of plant spacing on different attributes of BRRI Dhan $50^{\mathrm{X}}$

\begin{tabular}{|c|c|c|c|c|c|c|c|c|c|c|c|c|c|}
\hline \multirow{2}{*}{$\begin{array}{l}\text { Plant } \\
\text { spacing }\end{array}$} & \multirow{2}{*}{\multicolumn{2}{|c|}{$\begin{array}{l}\text { Straw } \\
\text { yield } \\
\text { (t/ha) }\end{array}$}} & \multirow{2}{*}{\multicolumn{2}{|c|}{$\begin{array}{l}\text { Biological } \\
\text { yield } \\
\text { (t/ha) }\end{array}$}} & \multirow{2}{*}{\multicolumn{2}{|c|}{$\begin{array}{c}\text { Harvest } \\
\text { index } \\
(\%)\end{array}$}} & \multicolumn{4}{|c|}{$\begin{array}{l}\text { Number weed population } \\
\mathrm{m}^{-2} \text { at }\end{array}$} & \multicolumn{3}{|c|}{$\begin{array}{l}\text { Weed dry matter (g } \\
\left.\mathrm{m}^{-2}\right) \text { at }\end{array}$} \\
\hline & & & & & & & $30 \mathrm{DA}$ & & 60 DAT & & $30 \mathrm{DA}$ & & $60 \mathrm{DAT}$ \\
\hline$S_{1}$ & 4.4 & $\mathrm{bc}$ & 9.2 & $\mathrm{c}$ & 52.0 & $\mathrm{a}$ & 49.2 & $\mathrm{~b}$ & 65.8 & $\mathrm{~d}$ & 2.3 & $\mathrm{a}$ & 3.0 \\
\hline$S_{2}$ & 3.2 & d & 6.6 & d & 52.0 & $\mathrm{a}$ & 61.3 & $\mathrm{a}$ & 74.9 & $\mathrm{c}$ & 2.8 & $\mathrm{a}$ & 3.3 \\
\hline $\mathrm{S}_{3}$ & 4.1 & $\mathrm{~cd}$ & 8.3 & $\mathrm{c}$ & 51.2 & $\mathrm{a}$ & 48.6 & $\mathrm{~b}$ & 84.3 & $\mathrm{a}$ & 2.2 & $\mathrm{a}$ & 3.6 \\
\hline $\mathrm{S}_{4}$ & 5.9 & $\mathrm{a}$ & 12.7 & $\mathrm{a}$ & 54.5 & $\mathrm{a}$ & 38.0 & $\mathrm{c}$ & 78.0 & $\mathrm{~b}$ & 2.2 & $\mathrm{a}$ & 3.2 \\
\hline $\mathrm{S}_{5}$ & 5.5 & $a b$ & 10.7 & $\mathrm{~b}$ & 50.3 & $\mathrm{a}$ & 55.9 & $a b$ & 74.6 & $\mathrm{c}$ & 2.5 & $\mathrm{a}$ & 3.1 \\
\hline $\operatorname{LSD}(0.05)$ & 1.1 & & 1.4 & & 5.9 & & 9.1 & & 2.9 & & 0.9 & & 0.7 \\
\hline $\mathrm{CV}(\%)$ & 3.6 & & 6.2 & & 6.5 & & 7.2 & & 8.9 & & 6.9 & & 5.6 \\
\hline
\end{tabular}

${ }^{\mathrm{X}}$ In a column, means having similar letter(s) are statistically similar and those having dissimilar letter(s) differ significantly at 0.05 level of probability

\section{Conclusion}

It can be concluded that $40 \mathrm{~cm} \times 40 \mathrm{~cm}$ plant spacing is optimum for growth and maximum yield of rice under System of Rice Intensification (SRI). Growth and yield contributing characters such as maximum dry matter (156.2 g/hill), number of tiller (44.0/hill), number of effective tiller (36.3/hill), number of filled grains (101.5/panicle), grain yield (6.9 t/ha), straw yield (5.9 t/ha), biological yield $(12.7 \mathrm{t} / \mathrm{ha})$ and harvest index $(54.5 \%)$ was found best from 40 x $40 \mathrm{~cm}$ plant spacing while minimum was observed from $25 \times 25 \mathrm{~cm}$ of plant spacing. 


\section{Reference}

Awan, T. H., Ahmad, M., Ali, R. A., Anwar, M. and Manzoor, Z. (2007).Contribution of different tillers with in a plant of super basmati to grain yield of rice. J. Agri. Res. 44(2): 237-243.

Awan, T. H., Manzoor, Z., Safdar, M. E. and Ahmad, M. (2006). Studies on the influence of primary, secondary and tertiary tillers on yield and yieldrelated traits in basmati-2000. Pakistan J. Sci. 59(1-2): 43-46.

Awan, T. H., Ali, R. I., Manzoor, Z. Ahmed, M. and Akhtar M. (2011). Effect of different nitrogen levels and row spacing on the performance of newly evolved medium grain rice variety, KSK133. J. Anim. Plant Sci. 21(2): 231-234.

Balasubramaniyan, P. and Palaniappan, S. P. (1991). Effect of high density population and fertilizer rate on growth and yield of low land rice.Indian J. Agron. 36(1): 10-13.

Baloch, A. W., Soomro, A. M., Javed, M. A. and Ahmed, M. (2002). Optimum plant density for high yield in rice.Asian J. Plant Sci.1: 25-27

Banik, P., Sarkar, B., Basmal, T., Ghosal, P. K. and Bagohi, D. K. (1997). Effect of different numbers and age of seedlings on rice (Oryza sativa $\mathrm{L}$.) cultivars in lowland plateau region of Bihar. Ind. J. Agron. 42: 265-268.

Bari, G., Mustafa, G., Soomro, A. M. and Baloch, A. W. (1984). Effect ofplant density on grain yield and yield components of differentvarieties and mutant strains of rice. Pak. J. Bot. 16: 169-174.

Batuwitage, G. (2000). System of Rice Cultivation (SRI). Ministry of Agriculture, Colombo, Srilanka. July, 2000.

Bozorgi, H. R., Faraji, A., Danesh, R. K., Keshavarz, A., Azarpour, E. and Tarighi, F. (2011). Effect of Plant Density on Yield and Yield Components of Rice. World Appl. Sci. J.12(11): 2053-2057.

BRRI (Bangladesh Rice Research Institute) (2012). Adhunik Dhaner Chash. Joydebpur, Dhaka. p.10.

Counce, P. A. 1987. Asymptotic and parabolic yield and linear nutrient content responses to rice population density. Agron. J. 79: 864-869.

Gomez, K. A. and Gomez, A. A. (1984). Statistical Procedure for Agricultural Research (2 ${ }^{\text {nd }}$ edn.). Int. Rice Res. Inst., A Willey Int. Sci. pp.28-192.

Gozubenli, H. (2010). Influence of planting pattern and plant density on the performance of maize hybrids in the eastern Mediterranean condition. Int. J. Agric. Biol. 12: 556-560.

IRRI (International Rice Research Institute) (1997). Rice Production Manual, p: 95. UPLB, Los Banos, The Philippines

Kandil, A. A., El-Kalla, S. E., Badawi, A. T. and El-Shayb, O. M. (2010). Effect of hill spacing, nitrogen levels and harvest date on rice productivity and grain quality. Crop Environ.1: 22-26.

Khan, M. B., Yasir, T. A. and Aman, M. (2005). Growth and yield comparison of different linseed genotypes planted at different row spacing. Int. J. Agric. Biol.7: 515-517.

Krishna, A., Biradarpatil, N. K., Manjappa, K. and Channappagoudar, B. B. (2008). Evaluation of System of Rice Intensification Cultivation, Seedling Age and Spacing on Seed Yield and Quality in Samba Masuhri (BPT-5204) Rice.Karnataka J. Agri. Sci.21(1): 20-25.

Lone, B. A., Badr-ul-Hassan, Ansar-ul-Haq, S. and Khan, M. H. (2010). Effect of seed rate, row spacing and fertility levels on relative economics of soybean (Glycine max L.) under temperate conditions.Afric. J. Agric. Res. 5: 322-324.

Miah, M. H. N., Karim, M. A., Rahman, M. S. and Islam, M. S. (1990). Performance of Nitrogen nutrients under different row spacing.Bangladesh J. Train. Dev. 3(2):31-34.

Mohaddesi, A., Abbasian, A., Bakhshipour, S. and Aminpanah, H. (2011).Effect of different levels of nitrogen and plant spacing on yield, yield components and physiological indices in high yield rice.Amer-Eur. J. Agric Environ.10: 893-900

Oad, F. C., Solangi, B. K., Samo, M. A., Lakho, A. A., Hassan, Z. U. and Oad, N. L. (2001). Growth, yield and relationship of rape seed under different row spacing. Int. J. Agric. Biol. 3: 475-476.

Rad, S. F., Mazaheri, D. and Banah, T. (1999). Effect of planting dates and plant density on yield and growth of cowpea line 29005. Seed and Plant 15(2): 84-89. 
Senanayake, N., De Datta, S. K., Naylor, R. E. L. and Thompson, W. J. (1991).Lowland rice apical development stages and cultivar differences detected by electron microscopy. Agron. J. 83: 1013-1023.

Shekari, K. (2001). The effect of planting date and density on yield and the parts of yield M.A degree Agronomy field, Islamic Azad university, Varamin branch , 98, p.

Singh, T. N., Singh, G. and Singh, H. P. (1983). Nitrogen fertilization and spacing to maximize upland rice yield. Int. Rice Res. Newsl. 86: 27.

Soratto, R. P. (2004). Nutrient exportation and grain quality of upland rice as influenced by plant density and row spacing. Seropedica, Brazil: Universidade Federal Rural do Rio de Janeiro (UFRRJ). Agronomia 36(1/2): 17-22.

Sridhara, C. J., Ramachandrappa, B. K., Kumarswamy, A. S. and Gurumurthy, K. T. (2011). Effect of genotypes, planting geometry and methods of establishment on root traits and yield of aerobic rice.Karnataka J. Agric. Sci. 24(2): 129-132.

Tohiduzzaman. (2011). Screening of rice varieties responsive to system of rice intensification (sri) in boro season. M. Sc. (Ag) Thesis. Dept. of Agronomy.Sher-e-Bangla Agricultural University, Dhaka, Bangladesh.

Veeramani, P. (2011). Enhancement of Mat Nursery management and planting pattern (using rolling markers) in System of Rice Intensification (SRI) Technique. Res. J. Agril. Sci. 2(2): 371-375.

Vijayakumar, M., singh, S. D. S., Prabhakaran, N. K. and Thiyagarajan, T. M. (2004). Effect of SRI practices on the yield attributes, yield and water productivity of rice. Acta Agron. 52: 399-408.

Wang, G. S. and Luo, H. M. (1998). Relationship between sowing density and sowing norm of rice varieties with different kilograin weight. Res. Agric. Mod. 19: 40-43.

Yoshida, S. (1981). Fundamentals of Rice Crop Science, IRRI, Philipines. pp. 1-41.

\section{Citation for this article (APA Style)}

Chakrabortty, S., Biswas, P. K., Roy, T. S., Mahmud, M. A. A., Mehraj, H., \& Uddin, A. F. M. J. (2014). Growth and Yield of Boro Rice (BRRI Dhan 50) as Affected by Planting Geometry Under System of Rice Intensification. Journal of Bioscience and Agriculture Research,02(01), 36-43. Retrieved October 18, 2014, from http://www.journalbinet.com/current-issue-jbar-1.html. 